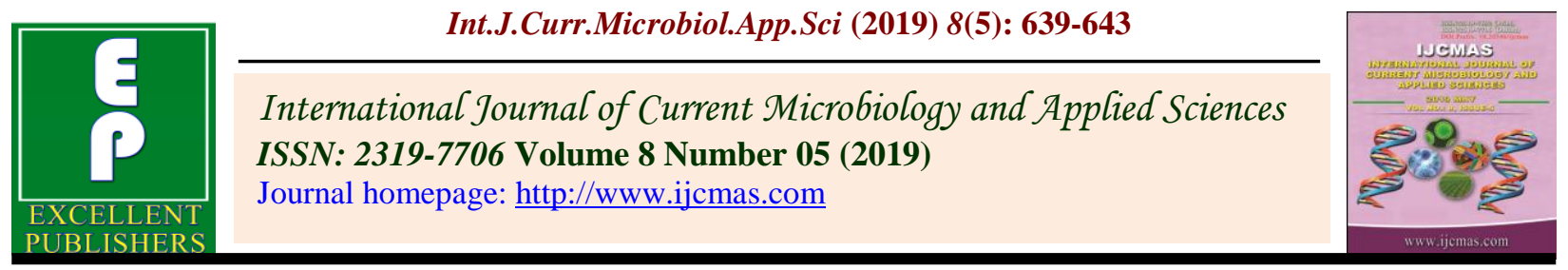

Original Research Article

https://doi.org/10.20546/ijcmas.2019.805.074

\title{
Effect of Different Pruning Intensities on Growth and Yield of Nectarine (Prunus persica L.var. nucipersica) cv. Snow Queen
}

\author{
Sharbat Hussain ${ }^{1 *}$, Khalid Rasool Dar², Amit Kumar' ${ }^{1}$, Showkat Maqbool ${ }^{2}$, \\ Zaffar Mehdi ${ }^{2}$ and M.A. Dar ${ }^{2}$ \\ ${ }^{1}$ Division of Fruit Science, Sher-e-Kashmir University of Agricultural Sciences and \\ Technology of Kashmir-190025, India \\ ${ }^{2}$ Faculty of Agriculture, Wadura Sopore, Sher-e-Kashmir University of Agricultural Sciences \\ and Technology of Kashmir-190025, India
}

*Corresponding author

\section{A B S T R A C T}

\section{Keywords}

Growth, Yield,

Nectarine, Pruning,

Pruning intensity

Article Info

Accepted:

07 April 2019

Available Online:

10 May 2019
The present investigation was carried to evaluate the effect of different pruning intensities on growth and yield of nectarine cv. Snow Queen at fruit research farm, SKUASTKashmir Shalimar Srinagar during the year 2016 and 2017. The experiment was laid out in randomized complete block design with nine pruning treatments and three replications. The results obtained revealed that there is a significant increase in shoot growth and leaf area with highest pruning intensity viz., 2/3rd head back and $20 \%$ thinning out. The results further revealed that with the increase in pruning intensities total yield was reduced however, marketable yield of quality fruits were increased. Highest total yield was obtained in those treatments where minimum pruning intensity i.e. $10 \%$ and $20 \%$ thinning out of the plants was performed.

\section{Introduction}

Nectarines (Prunus persica L. Batsch var. nucipersica) are one of the newly introduced crop in Kashmir valley. The peach and nectarine plants resemble with each other and it is very difficult to distinguish a peach tree from a nectarine tree, except the surface of the fruit skin which is smooth and fuzz less in nectarine. Nectarines are believed to have originated from peach by mutation and the smooth skinned fruit in nectarines is governed by the presence of single recessive gene where as in peaches fuzzy skin is due to a dominant gene. Peach is the third most important temperate fruit crop of India and in Jammu and Kashmir, the area under peach cultivation corresponds to 2523 hectares with an annual production of 5472 Metric tonnes $^{[1]}$. Nectarines have a habit to produce large numbers of flowers and if the environmental conditions are conducive, may set excessively large number of fruits per tree and thereby reduce the possibility of getting commercial fruit size with quality fruit at harvest ${ }^{[4]}$. To avoid over cropping, the 
number of fruits per tree must be regulated to promote return bloom ${ }^{[3]}$. Pruning being an important horticultural operation not only restores balance between shoot and root system but also maintains growth and vigour of shoots by allowing only fewer growing points to grow vigorously and regulate the crop [4]. Performance of nectarine trees depends heavily on the proper pruning annually and one of the main purposes of pruning in nectarines is to produce shoots of 40 to $60 \mathrm{~cm}$ in length because these are the shoots on which flower bud development is most numerous ${ }^{[4]}$.

Nectarine require heavy and regular pruning because fruiting occurs laterally on last year shoot which bears only once in its life time and becomes barren afterwards. Hence, they require a heavy pruning to strike a balance between vegetative growth and fruitfulness, otherwise fruiting area on the shoots gets far away, which becomes unmanageable. If the trees are not pruned annually, the volume of fruiting wood reduces each year [10]. However, pruning also makes the canopy more open and improves pest control by allowing better spray penetration into the tree, air movement throughout the canopy is increased, which improves drying conditions and reduces severity of many diseases, while different pruning intensities are also performed in nectarine tree to maintain tree size and shape. Sufficient information is available on peach pruning in the world, however, the physiology of pruning is not still well understood in nectarine. Therefore, the present study was conducted to evaluate the influence of pruning on growth and yield in nectarine, cv Snow Queen.

\section{Materials and Methods}

The present experiment was conducted on five year old nectarine (Prunus persica (L.) Batsch var. nucipersica) plantation having uniform plant growth and vigour at a spacing of 3 X 3 meter in the Research Farm of Fruit Science at Sher-e-Kashmir University of Agricultural Sciences \& Technology of Kashmir, Shalimar campus during the year 2016 and 2017. The experiment comprised of 9 treatments each replicated thrice in a randomized block design. The data were recorded on different growth, flowering and yield parameters with standard procedures. The average length of annual shoot was measured with measuring tape at the end of growing season during both the years.

The tree height was measured in centimeter with the help of graduated flag staff and the leaf area was estimated with the help of automatic Leaf Area Meter (221 systronics) in the laboratory and average values were expressed in square centimetre $\left(\mathrm{cm}^{2}\right)$. Fruit yield was estimated by taking weight of all the fruits harvested from the tree under each treatment and expressed as $\mathrm{kg} /$ plant. The pruning were performed during $2^{\text {nd }}$ week of December with different pruning intensities viz., $\mathrm{T}_{1}$ (control) - Corrective pruning Removal of dead diseased and criss cross branches; $\mathrm{T}_{2}-\mathrm{T}_{1}+$ heading back removing one third of the branch; $\mathrm{T}_{3}-\mathrm{T}_{1}+$ heading back removing two third of the branch; $\mathrm{T}_{4}-\mathrm{T}_{1}$ + thinning out percent of the one year old branches; $\mathrm{T}_{5}-\mathrm{T}_{1}+$ thinning out 20 per cent of the one year old branches; $\mathrm{T}_{6}-\mathrm{T}_{1}+$ heading back removing one third of the branch and thinning out ten percent of the one year old branches; $\mathrm{T}_{7}-\mathrm{T}_{1}+$ heading back removing one third of the branch and thinning out 20 percent of the one year old branches; $\mathrm{T}_{8^{-}} \mathrm{T}_{1}+$ heading back removing two third of the branch thinning out 10 percent of the one year old branches; $\mathrm{T}_{9^{-}} \mathrm{T}_{1}+$ heading back removing two third of the branch thinning out 20 percent of the one year old branches. The data generated from these investigations were appropriately designed, computed and tabulated under Randomized complete Block 
Design (RCBD). The data was analysed and level of significance was tested for different variables at 5 per cent level of significance.

\section{Results and Discussion}

The perusal of the data presented in Table 1 reveals that fruit yield was significantly affected by different pruning intensities. The highest fruit yield were recorded in treatment $\mathrm{T}_{1}$ (control) followed by $\mathrm{T}_{4}\left(\mathrm{~T}_{1}+10 \% \mathrm{TO}\right)$ which were least pruned. However, lowest fruit yield was obtained under treatment $\mathrm{T}_{9}$ $\left(\mathrm{T}_{1}+\left(2 / 3^{\text {rd }} \mathrm{HB}+20 \% \mathrm{TO}\right)\right.$ which were severely pruned plants. This is due the fact that the severe pruning reduced the number of floral buds and fruiting area of wood and heavy pruning reduced the fruit set due to the active utilization of carbohydrates, nutrients, hormones and water content by the newly grown vegetative shoots, also heading cuts decreases yield more than thinning cuts and many small cuts decrease fruiting more than a few larger cuts as theses cuts reduced the amount of wood. These results are in agreement with others authors findings $[6,7,8,9,10]$

Table.1 Effect of different pruning intensities on yield, annual shoot growth, plant height and leaf area of nectarine cv. snow queen

\begin{tabular}{|c|c|c|c|c|c|c|c|c|c|}
\hline \multirow{2}{*}{\multicolumn{2}{|c|}{ Treatments }} & \multicolumn{2}{|c|}{$\begin{array}{l}\text { Annual shoot } \\
\text { extension growth } \\
(\mathrm{cm})\end{array}$} & \multicolumn{2}{|c|}{$\begin{array}{l}\text { Plant height } \\
(\text { (cm) }\end{array}$} & \multicolumn{2}{|c|}{$\begin{array}{c}\text { Leaf area } \\
\left(\mathrm{cm}^{2}\right)\end{array}$} & \multicolumn{2}{|c|}{$\begin{array}{c}\text { Fruit yield } \\
\left(\text { kg tree }^{-1}\right)\end{array}$} \\
\hline & & 2016 & 2017 & 2016 & 2017 & 2016 & 2017 & 2016 & 2017 \\
\hline $\mathbf{T}_{1}$ & Corrective pruning & 43.13 & 42.16 & 258.53 & 266.37 & 33.23 & 33.22 & 18.43 & 19.78 \\
\hline $\mathbf{T}_{2}$ & $\begin{array}{l}\mathrm{T}_{1}+1 / 3^{\mathrm{rd}} \text { Heading } \\
\text { Back }\end{array}$ & 51.14 & 50.21 & 250.16 & 257.39 & 35.28 & 35.13 & 15.16 & 16.48 \\
\hline $\mathbf{T}_{\mathbf{3}}$ & $\begin{array}{l}\mathrm{T}_{1}+2 / 3^{\text {rd }} \text { Heading } \\
\text { Back }\end{array}$ & 54.48 & 55.14 & 244.47 & 250.88 & 37.14 & 36.51 & 12.41 & 13.32 \\
\hline $\mathbf{T}_{4}$ & $\begin{array}{l}\mathrm{T}_{1}+10 \% \\
\text { Thinnning out }\end{array}$ & 44.31 & 43.67 & 259.56 & 267.85 & 33.78 & 33.17 & 17.21 & 18.68 \\
\hline $\mathbf{T}_{5}$ & $\begin{array}{l}\mathrm{T}_{1}+20 \% \\
\text { Thinnning Out }\end{array}$ & 45.51 & 44.69 & 261.86 & 270.25 & 34.18 & 33.77 & 16.48 & 17.61 \\
\hline $\mathbf{T}_{6}$ & $\begin{array}{l}\mathrm{T}_{1}+1 / 3^{\mathrm{rd}} \text { Heading } \\
\text { Back }+10 \% \\
\text { Thinnning Out }\end{array}$ & 52.23 & 51.11 & 252.20 & 260.02 & 35.62 & 34.68 & 14.74 & 15.44 \\
\hline $\mathbf{T}_{7}$ & $\begin{array}{l}\mathrm{T}_{1}+1 / 3^{\text {rd }} \text { Heading } \\
\text { Back }+20 \% \\
\text { Thinnning Out }\end{array}$ & 53.18 & 52.54 & 253.72 & 261.37 & 36.43 & 35.56 & 13.66 & 14.81 \\
\hline $\mathbf{T}_{8}$ & $\begin{array}{l}\mathrm{T}_{1}+2 / 3^{\text {rd }} \text { Heading } \\
\text { Back }+10 \% \\
\text { Thinnning Out }\end{array}$ & 55.36 & 56.47 & 246.51 & 253.39 & 37.54 & 38.16 & 12.02 & 12.62 \\
\hline $\mathbf{T}_{9}$ & $\begin{array}{l}\mathrm{T}_{1}+2 / 3^{\mathrm{rd}} \text { Heading } \\
\text { Back }+20 \% \\
\text { Thinnning Out }\end{array}$ & 56.25 & 57.11 & 247.21 & 254.29 & 38.23 & 38.45 & 11.73 & 12.07 \\
\hline \multicolumn{2}{|c|}{$C D_{(p \leq 0.05)}$} & 1.36 & 1.51 & 1.41 & 1.62 & 0.86 & 0.82 & 1.19 & 1.34 \\
\hline
\end{tabular}

$* \mathrm{HB}=$ Heading Back, $\mathrm{TO}=$ Thinning Out 
The data on annual shoot growth; leaf area and plant height given in Table 1 was significantly affected by different pruning intensities. The highest shoot length and leaf area were observed in treatment $\mathrm{T}_{9}\left(\mathrm{~T}_{1}+\right.$ $\left(2 / 3^{\text {rd }} \mathrm{HB}+20 \% \mathrm{TO}\right)$ and lowest under control. This is due to the fact that severe pruning induces the development of longer and often more numerous shoots and the average length of new shoots is greater than the shoots of unpruned trees, which results in higher amount of photosynthates and nutrients that enhances cell division and formation of more tissues resulting into more vegetative growth.

Pruning also alters the hormonal and nutritional translocation in the plants, which promote development of vascular system and activate nutrient transport, as these results are in line with the findings others authors ${ }^{[2,5,6,10]}$. However the highest plant height was recorded under light pruning treatments viz., $\mathrm{T}_{1}$ (control), $\mathrm{T}_{4}\left(\mathrm{~T}_{1}+10 \% \mathrm{TO}\right)$ and $\mathrm{T}_{5}\left(\mathrm{~T}_{1}+\right.$ $20 \%$ TO) compared to sever pruning treatments.

It is due to the reason that growth of long shoots is not enough to equal the growth of the unpruned tree plus the amount of wood that has been cut away. Thus pruning to a certain extent effectively control growth and cause dwarfing effect on pruned plants. These results are in agreement with others authors finding ${ }^{[4,6]}$.

From this study, it is concluded that the best results in terms of vegetative growth were obtained with $2 / 3^{\text {rd }} \mathrm{HB}+20 \% \mathrm{TO}$; but the fruit yield was lower in this treatment. However, yield was found highest with treatment where minimum pruning intensity i.e. $10 \%$ and $20 \%$ thinning out of the plants was performed. The increase in pruning intensity also decreased the time taken for initial bloom of the plants.

\section{Acknowledgement}

Author(s) are highly thankful to the division of fruit science SKUAST-K and national fellowship scholarship for higher studies of ST students (NFST) by Ministry of Tribal Affairs Govt. of India for their active cooperation during the present investigation.

\section{References}

Anonymous. 2018. Statistical data. Department of Horticulture, Jammu and Kashmir.

Bussi, C., Lescourret J, Genard M, Habib R. 2005. Pruning intensity and fruit load influence vegetative and fruit grow thin an early maturing peach tree cv. Alexandra. Fruits, 60(2): 133-142.

Byers, RE., Costa G. and Vizzotto G. 2003. Flower and fruit thinning of Peach and other Prunus. Horticultural Reviews, 28:351-392.

Faust, M., Effect of pruning on hormonal pattern of fruit trees. 1989, pp 296301. In: Physiology of Temperate Zone Fruit Trees: Wiley Interscience. New York.

Myriam S., Bussi C, Lescourret F, Genard M, Habib R, Gilreath J. 2005. Pruning intensity and fruit load influence on vegetative and fruit growth in 'Alexandra' peach. Proc. Fla. State. Hort. Soc., 118:266-269.

Rathi, DS., Dimri DC, Nautiyal MC, Kumar A. 2003. Pruning responses to shoot growth, fruit set and yield in peach. Indian Journal of Horticulture, 60(2): 151-153

Robinson TL, Andersen RL, Hoying SA. 2006. Performance of six high density peach training systems in the North eastern United States. Acta Horticulturae. 713: 311-320.

Singh Devi, Chauhan J S and Kainth N S. 1997. Pruning in peach: A review. 
Agriculturae Reviews (Karnal), Thakur, N., Rana VS. 2012. Effect of 18(3/4): 147-154. different pruning intensities on the

Singh, D., Chauhan JS. 2002. Studies on pruning and nitrogen fertilization in peach. Indian Journal of Agricultural growth, flowering, yield and quality of nectarine. Indian Journal of Research, 36(2): 128-132.

\section{How to cite this article:}

Sharbat Hussain, Khalid Rasool Dar, Amit Kumar, Showkat Maqbool, Zaffar Mehdi and Dar, M.A. 2019. Effect of Different Pruning Intensities on Growth and Yield of Nectarine (Prunus persica L.var. nucipersica) cv. Snow Queen. Int.J.Curr.Microbiol.App.Sci. 8(05): 639-643. doi: https://doi.org/10.20546/ijcmas.2019.805.074 